\title{
Evaluasi Penatausahaan Barang Milik Daerah di Badan Pengelolaan Keuangan Kabupaten Aceh Singkil
}

\section{Evaluation of the Administration of Regional Property in the Aceh Singkil Regency Financial Management Agency Arief Poedjianto ${ }^{1}$, Warjio ${ }^{2} \&$ Isnaini $^{3}$}

1) Magister Program Studi Administrasi Publik, Universitas Medan Area, Indonesia

2) Departemen Ilmu Politik, Fakultas Ilmu Sosial dan Ilmu Politik,

Universitas Sumatera Utara, Indonesia

3) Fakultas Hukum, Universitas Medan Area, Indonesia

\begin{abstract}
Abstrak
Penelitian ini bertujuan untuk mengevaluasi penatausahaan barang milik daerah di Badan Pengelolaan Keuangan Kabupaten Aceh Singkil yang mempunyai fungsi pengelolaan barang milik daerah. Penelitian ini menggunakan metode penelitian kualitatif. Observasi partisipasi adalah metode pengumpulan data yang digunakan untuk menghimpun data penelitian. Dari hasil penelitian diketahui bahwa evaluasi terhadap prosedur penatausahaan aset tetap, meliputi: pembukuan, inventarisasi dan pelaporan sertakelengkapan kartu inventaris barang, diperoleh rata-rata tingkat kesesuaian penatausahaan aset tetap pada Pemerintah Kabupaten Aceh Singkil adalah sebesar $57 \%$ yang berarti penatausahaan aset tetap pada Pemerintah Kabupaten Aceh Singkil memenuhi kriteria cukup sesuai dengan Permendagri No. 19 Tahun 2016. Kendala-kendala yang dihadapi dalam penatausahaan aset tetap, adalah: (1) rendahnya etos kerja dan disiplin pengurus barang pengguna, (2) keterbatasan data pendukung aset tetap, (3) minimnya pendidikan dan pelatihan yang berhubungan dengan pengelolaan barang milik daerah, (4) rendahnya koordinasi dan komitmen pihak-pihak yang terlibat dalam penatausahaan aset tetap, dan (5) belum adanya penggunaan aplikasi dalam pencatatan barang milik daerah.
\end{abstract}

Kata Kunci: Evaluasi, Penatausahaan, Barang Milik Daerah, Kartu Inventaris Barang

\begin{abstract}
This study aimed to evaluate the administration of property in the area of Financial Management Agency of Aceh Singkil Regency which has the function of asset management area. This study used qualitative research methods. Observation is the participation of the data collection methods used to collect research data. The survey results revealed that the evaluation of the procedure of administration of fixed assets, including: accounting, inventory and reporting as well as the completeness of the card inventory of goods, gained an average level of suitability administration of fixed assets for the Government of Aceh Singkil Regency is 57\%, which means the administration of fixed assets for the Government Aceh Singkil meet enough criteria in accordance with Regulation No. 19 Year 2016. The obstacles faced in the administration of fixed assets are (1) The lack of work ethic and discipline of user goods (2) The limited data of supporting fixed assets, (3) Lack of education and training related to the management of local goods, (4) The low coordination and commitment of the parties involved in the administration of the fixed assets, and (5) No use of applications in the recording of local goods.
\end{abstract}

Keywords: Evaluation, Administration, Goods Locality, Inventory Card

How to Cite: Poedjianto A, Warjio \& Isnaini (2020). Evaluasi Penatausahaan Barang Milik Daerah di Badan Pengelolaan Keuangan Kabupaten Aceh Singkil. Strukturasi: Jurnal Ilmiah Magister Administrasi Publik, 1(1): 43-51,

*E-mail: abdullahafifudin@gmail.com 


\section{PENDAHULUAN}

Sistem Manajemen Aset Pemerintah Daerah sejak diberlakukannya undangundang otonomi daerah mengalami banyak perubahan. Pemerintah daerah dituntut agar mengarah kepada model manajeman aset yang efektif dalam pengadaan dan pengelolaan, efisien dalam pemanfaatan dan pemeliharaan serta transparan dan dapat dipertanggungjawabkan. Beberapa langkah dalam manajemen aset pemerintah daerah meliputi; inventarisasi aset, legal audit, penilaian aset, pemanfaatan aset serta pengawasan dan pengendalian dengan sistem informasi manajemen aset (SIMA).

Penatausahaan barang milik daerah meliputi pembukuan, inventarisasi, dan pelaporan. Hasil dari proses pembukuan dan inventarisasi diperlukan dalam melaksanakan proses pelaporanbarang milik daerah yang dilakukan oleh kuasa pengguna barang, pengguna barang, dan pengelola barang. Hasil penatausahaan barang milik daerah digunakan dalam rangka penyusunan neraca pemerintah pusat/daerah setiap tahun danpengamanan administratif terhadap barang milik daerah.

Pelaksanaan pengelolaan barang daerah dalam hal inventarisasi belum jelas, lengkap dan dapat dipertanggungjawabkan berdasarkan dokumen yang ada sehingga Badan Pengelolaan Keuangan Kabupaten Aceh Singkil sebagai penanggung jawab penatausahaan barang dalam lingkungan wewenangnya sekaligus penanggungjawab pengelolaan barang daerah belum dapat menyusun buku induk inventaris (Sari \& Ritonga,2016).

Pengelolaan barang milik daerah merupakan bagian dari pengelolaan keuangan daerah (Suyono \& Kadir,2014). Pencatatan barang daerah pada Satuan Kerja Perangkat Daerah (SKPD) sangat penting dikarenakan catatan tersebut dijadikan obyek audit oleh Badan Pemeriksa Keuangan (BPK) dalam meyakini penyajian laporan keuangan Satuan Kerja Perangkat Daerah (SKPD) dan pemerintah daerah. Hasil penatausahaan barang milik daerah ini nantinya dapat digunakan dalam rangka penyusunanneraca Satuan Kerja Perangkat Daerah (SKPD) dan pemerintah daerah setiap tahun dan pengamanan administrasi barang milik daerah. Denganpenatausahaan secara tertib, maka akan dihasilkan angka-angka yang tepat danakurat yang berdampak pada tersedianya database yang memadai dalam menghasilkanlaporan aset daerah di neraca dengan angka yang tepat dan akurat.

Kepala SatuanKerja Perangkat Daerah (SKPD) selaku PenggunaBarang milikdaerah, berwenang dan bertanggungjawab melakukan pencatatan dan inventarisasi barang milik daerah yang berada dalam penguasaannya. Pencatatan barang milik daerah pada SKPDs angat penting dikarenakan catatan tersebut dijadikan obyek audit oleh Badan Pemeriksa Keuangan Republik Indonesia (BPK RI) dalam meyakini penyajian laporan keuangan SKPD dan pemerintah daerah. Hasil penatausahaan barang milik daerah ini nantinya dapat digunakan dalam rangka (a) penyusunan neraca pemerintah daerah setiap tahun (b) perencanaan kebutuhan pengadaan dan pemeliharaan barang milik daerah setiap tahun untuk digunakan sebagai bahan penyusunan rencana anggaran dan (c) pengamanan administrasi barang milik daerah. Dengan penatausahaan secara tertib, maka akan dihasilkan angka-angka yang tepat dan akurat yang berdampak pada tersedianya sumber data yang memadai 
dalam menyusun perencanaan kebutuhan dan penganggaran dan akan dihasilkan pula laporan barang milik daerah di neraca dengan angka yang tepat dan akurat. Berdasarkan observasi dari surat-surat yang masuk ke Badan Pengelolaan Keuangan Kabupaten Aceh Singkil khususnya Bidang Kekayaan dan Aset Daerah berkaitan dengan kewajiban Satuan Kerja Perangkat Daerah (SKPD) yang memberikanlaporan administrasi barang milik daerah, masih ada ditemui beberapa Satuan Kerja Perangkat Daerah (SKPD) yang belummenyampaikan laporan administrasi barang milik daerah. Sehubungan dengan hal itu makaSKPD dalam pelaksanaan kegiatan pengelolaan barang milik daerah masih banyakditemui permasalahan sebagai berikut:

1. Pendaftaran dan pencatatan barang milik daerah yang status penggunaanya berada pengguna barang ke daftar pengguna barang menurut penggolongan dan kodefikasi barang belum sepenuhnya memadai.

2. Pengguna barang belum melakukan inventarisasi barang milik daerah dalam 5 (lima) tahun terakhir.

3. Laporan barang pengguna semesteran dan tahunan belum sepenuhnya memadai.

4. Rendahnya kinerja pengurus barang pengguna dan pembantu pengurus barang pengguna.

Berdasarkan hasil pemeriksaan Badan Pemeriksa Keuangan (BPK)Tahun 2017bernilai sebesar Rp.31 miliar dianggap belum memadai, hasil temuan tersebut menunjukan penyimpangan yang terbesar adalah pencatatan aset tidak tertib dan atau tidak sesuai dengan ketentuan. Terdapat beberapa kasus yang terkait dengan barang milik daerah yang pencatatan aset tidak tertib dan atau tidak sesuai, diantaranya: pencatatan aset tidak memiliki tahun perolehan; pencatatan aset bernilai Rp. 0,00 dan Rp. 1,00; aset dicatat dengan harga gelondongan; biaya setelah perolehan aset belum didistribusikan ke aset induk. Menurut Siregar (2004), aset tetap merupakan salah satu komponen penting dari suatu neraca yang harus ditampilkan sesuai dengan nilai yang sebenarnya. Oleh sebab itu, keakuratan data aset tetap sangat dibutuhkan dalam mendukung laporan keuangan agar dapat tersaji secara wajar.

Untuk mendapatkan data aset tetap yang akurat, harus didukung dengan pencatatan dan rincian yang memadai. Data aset tetap akan lengkap dan dipercaya jika penatausahaan aset antara fisik aset, dokumen kepemilikan/pendukung, penatausahaan dalam buku inventaris mempunyai kesesuaian. Untuk itu diperlukan adanya proses penatausahaan yang sistematis dan memadai untuk meningkatkan tingkat kepercayaan terhadap laporan keuangan daerah. Kepercayaan tersebut meliputi kebenaran terhadap lokasi/alamat aset, jumlah aset, pengguna aset, spesifikasi aset dan nilai aset. Apabila kepercayaan terhadap aset tesebut sangat kurang, maka neraca juga akan sulit dipercaya kewajarannya. Selain itu, BPK selaku auditor akan lebih mudah menelusuri aset dan tidak akan menemukan keraguan dalam menilai tingkat kewajaran keberadaaan aset baik secara administrasi ataupun secara fisik (Yusuf, 2010).

\section{METODE PENELITIAN}


Penelitian ini bermaksud mengetahui dan menggambarkan bagaimana Evaluasi Penatausahaan Barang Milik Daerah di Badan Pengelolaan Keuangan Kabupaten Aceh Singkil.

Dengan demikian penelitian akan mengarah pada penelitian deskriptif kualitatif yang lebih menekankan pada pengungkapan makna dari evaluasi penatausahaan barang milik daerah serta faktor-faktor kendalanya.

Penelitian kualitatif adalah suatu pendekatan yang juga disebut pendekatan investigasi karena biasanya peneliti mengumpulkan data dengan cara bertatap muka langsung dan berinteraksi dengan orang-orang di tempat penelitian (McMillan \& Schumacher, 2003). Penelitian kualitatif juga bisa dimaksudkan sebagai jenis penelitian yang temuan-temuannya tidak diperoleh melalui prosedur statistik atau bentuk hitungan lainnya (Strauss \& Corbin, 2003).

Penelitian dilakukan selama \pm 3 (tiga) bulan sejak bulan Desember 2018 hingga bulan Februari 2019 di Badan Pengelolaan Keuangan Kabupaten Aceh Singkil sebagai SKPD yang mempunyai fungsi pengelolaan barang milik daerah selaku pejabat pengelola keuangan daerah (Laniari \& Muda, 2016).

Penelitian ini menggunakan pendekatan analisis deskriptif kualitatif yaitu mendiskripsikan suatu situasi yang bersifat faktual dengan mengkaji permasalahanpermasalahan yang terjadi pada saat sekarang guna memperoleh gambaran yang menyeluruh tentang permasalahan pada rumusan masalah. Penelitian ini bermaksud meneliti dan mengumpulkan informasi rinci berdasarkan fakta-fakta yang ada tentang penatausahaan aset tetap pada Badan Pengelolaan Keuangan Kabupaten Aceh Singkil. Penelitian ini berupaya memperoleh deskripsi secara lengkap dan akurat dengan mengevaluasi penatausahaan aset tetap yang telah dilakukakan pada Badan Pengelolaan Keuangan Kabupaten Aceh Singkil

Jenis data yang digunakan dalam penelitian ini terdiri dari data primer dan data sekunder. Data primer dalam penelitian ini diperoleh langsung dari informan penelitian. Data primer diperoleh melalui wawancara mendalam dengan informan penelitian tentang penatausahaan aset tetap pada Badan Pengelolaan Keuangan Kabupaten Aceh Singkil. Informan penelitian ini terdiri dari: Pengelola Barang, Pejabat Penatausahaan Barang dan Pengurus Barang Pengguna.

Sumber data sekunder pada penelitian ini adalah catatan atau basis data yang sudah ada, diantaranya: dokumen penatausahaan aset tetap Badan Pengelolaan Keuangan Kabupaten Aceh Singkilyang menjadi objek evaluasi adalah Kartu Inventaris Barang (KIB). KIB memuat data barang (jenis, lokasi, jumlah, ukuran, harga, tahun pembelian, asal barang, keadaan barang) dan sebagainya harus diisi dengan lengkap teratur dan berkelanjutan. Kelengkapan informasi dalam kartu inventaris barang mempunyai peran yang sangat penting dalam rangka: (1) pengendalian, pemanfaatan, pengamanan dan pengawasan aset tetap; (2) untuk pemanfaatan setiap aset tetap secara maksimal sesuai dengan tujuan dan fungsinya masing-masing; (3) menunjang prosedur tugas pemerintah. Apabila kartu inventaris barang diisi dengan lengkap dan benar sesuai dengan keadaan yang sebenarnya, maka pihak- pihak yang berkepentingan 
akan mudah untuk mengetahui dan menelusuri keberadaan aset tetap tersebut. serta peraturan perundangan yang berlaku.

Teknik pengumpulan data merupakan cara untuk mengumpulkan data yang dibutuhkan untuk menjawab rumusan masalah penelitian (Juliansyah, 2010)

Adapun cara untuk mengumpulkan data yang dipergunakan untuk memperoleh informasi dalam penelitian ini yaitu: wawancara, observasi dan dokumentasi.

Observasi partisipasi (participant observation) adalah metode pengumpulan data yang digunakan untuk menghimpun data penelitian melalui pengamatan dan pengindraan dimana observer atau peneliti benar-benar terlibat dalam keseharian responden.

Teknik pengolahan data dalam penelitian ini dilakukan dengan membandingkan penatausahaan aset tetap pada Badan Pengelolaan Keuangan Kabupaten Aceh Singkil dengan penatausahaan aset tetap menurut Permendagri No. 19 Tahun 2016. Evaluasi dilakukan dengan membandingkan, sebagai berikut:

1. Bagaimana tingkat kesesuaian penatausahaan aset tetap di Badan Pengelolaan Keuangan Kabupaten Aceh Singkil dengan penatausahaan berdasarkan Peraturan Menteri Dalam Negeri Republik Indonesia Nomor 19 Tahun 2016?

2. Kelengkapan KIB SKPD Kabupaten Aceh Singkil dengan kriteria yang dibuat berdasarkan Permendagri No. 19 Tahun 2016.

3. Penatausahaan aset tetap terdiri dari kegiatan pembukuan, inventarisasi dan pelaporan, ditetapkan 5 kriteria untuk kegiatan pembukuan, 1 kriteria untuk kegiatan inventarisasi dan 7 kriteria untuk kegiatan pelaporan. Rincian kriteria untuk masing-masing kegiatan penatausahaan dapat dilihat pada tabel 3.1 berikut ini:

Evaluasi kelengkapan KIB SKPD Kabupaten Aceh Singkil, dilakukan pada KIB-A Tanah, KIB-B Peralatan dan Mesin, KIB-C Gedung dan Bangunan, KIB- D Jalan, Irigasi dan Jaringan, KIB-E Aset Tetap lainnya, KIB-F Kontruksi dalam Pengerjaan. Sebagai sampel dalam penelitian ini, digunakan KIB Dinas Pendidikan dan Kebudayaan Kabupaten Aceh Singkil. Dengan pertimbangan bahwa Dinas Pendidikan dan Kebudayaan Kabupaten Aceh Singkil merupakan SKPD dengan jumlah aset tetap yang paling banyak dan paling lengkap diantara SKPD lainnya pada Pemerintah Kabupaten Aceh Singkil. Karena banyaknya item barang yang tercatat dan terdaftar pada Dinas Pendidikan dan Kebudayaan Kabupaten Aceh Singkil, maka penelitian ini membatasi jumlah item aset tetap yang akan dijadikan sampel dalam penelitian ini adalah 50 (lima puluh) item aset tetap untuk setiap KIB-A, KIB-B, KIB-C, KIB-D, KIB-E dan KIB-F dengan menggunakan metode simple random sampling. Untuk kartu inventaris barang yang memiliki aset tetap kurang dari limapuluh item, seluruh item aset tetap dipergunakan sebagai sampel penelitian.

\section{HASIL DAN PEMBAHASAN}

\section{Evaluasi Penatausahaan Aset Tetap}

Evaluasi penatausahaan aset tetapdi Badan Pengelolaan Keuangan Kabupaten Aceh Singkil dilakukan dengan cara membandingkan penatausahaan penatausahaan 
aset tetapdi Badan Pengelolaan Keuangan Kabupaten Aceh Singkilsesuai dengan Permendagri No. 19 Tahun 2016. Evaluasi penatausahaan aset tetapdi Badan Pengelolaan Keuangan Kabupaten Aceh Singkil dilakukan pada prosedur penatausahaan aset tetap dan dokumen penatausahaan aset tetap (Siregar, Kusmanto, et .all, 2016). Prosedur penatausahaan aset tetap meliputi kegiatan pembukuan, inventarisasi dan pelaporan. Dokumen penatausahaan aset tetap yang dievaluasi adalah kartu inventaris barang yang terdiri dari KIB-A, KIB-B, KIB-C, KIB-D, KIB-E dan KIB-F.

Dari hasil evaluasi terhadap prosedur penatausahaan aset tetap dan dokumen penatausahaan aset tetap, diperoleh rata-rata tingkat kesesuaian penatausahaan aset tetap pada Pemerintah Kabupaten Aceh Singkiladalah sebesar 57\% yang berarti penatausahaan aset tetap pada Pemerintah Kabupaten Aceh Singkil memenuhi kriteria cukup sesuai dengan Permendagri No. 19 Tahun 2016. Hasil evaluasi penatausahaan aset tetap pada Pemerintah Kabupaten Aceh Singkil dapat dilihat pada tabel berikut ini:

Tabel 4.1. Hasil Evaluasi Penatausahaan Aset Tetap

\begin{tabular}{llll}
\hline No. & \multicolumn{1}{c}{ Objek Yang Dievaluasi } & Tingkat Kesesuaian & Kriteria Penyesuaian \\
\hline 1 & Evaluasi Prosedur Penatausahaan Aset Tetap & $34 \%$ & Sebagian Kecil \\
2 & Kelengkapan Kartu Inventaris Barang & $81 \%$ & Sebagian Besar \\
\hline Rata & Rata & $57 \%$ & Netral \\
\hline
\end{tabular}

Sumber: Pengolahan Data, 2017

Hasil evaluasi penatausahaan aset tetap Pemerintah Kabupaten Aceh Singkil menunjukkan bahwa penatausahaan aset tetap pada Pemerintah Kabupaten Aceh Singkil memenuhi kriteria cukup sesuai dengan Permendagri No. 19 Tahun 2016. Berdasarkan LHP BPK RI atas LKPD Kabupaten Aceh Singkil TA 2017, pengecualian atas kewajaran LKPD Pemerintah Kabupaten Aceh Singkil terutama pada proses penatausahaan aset, dimana aset tetap Pemerintah Kabupaten Aceh Singkil tidak didukung dengan dokumen pendukung dan rincian data aset yang memadai. Hal ini didukung dengan hasil penelitian yang menunjukkan bahwa kelemahan dalam penatausahaan aset tetap Pemerintahan Kabupaten Aceh Singkil adalah pada kelengkapan kartu inventaris barang yang ditunjukkan dengan hasil evaluasi penatausahaan aset tetap sebesar 81\% yang hanya memenuhi kriteria sebagian besarsesuai dengan Permendagri No. 19 Tahun 2016.

\section{Evaluasi Prosedur Penatausahaan Aset Tetap}

Prosedur penatausahaan aset tetap pada Pemerintah Kabupaten Aceh Singkil dievaluasi dengan menggunakan kriteria berdasarkan Permendagri No. 19 Tahun 2016. Kegiatan pembukuan dievaluasi dengan menggunakan 5 kriteria, kegiatan inventarisasi menggunakan 1 kriteria dan kegiatan pelaporan menggunakan 7 kriteria. Hasil evaluasi terhadap prosedur penatausahaan aset tetap pada Pemerintah Kabupaten Aceh Singkil yang terdiri dari kegiatan pembukuan, inventarisasi dan pembukuan, diperoleh tingkat kesesuaian rata-rata sebesar $34 \%$, yang berarti prosedur penatausahaan aset tetap pada Pemerintah Kabupaten Aceh Singkil dilakukan sebagian kecil sesuai dengan 
Permendagri No. 19 Tahun 2016. Rangkuman hasil evaluasi prosedur penatausahaan aset tetap pada Pemerintah Kabupaten Aceh Singkil dapat dilihat pada tabel berikut ini:

Tabel 4.2 Hasil Evaluasi Prosedur Penatausahaan Barang Milik Daerah

\begin{tabular}{llll}
\hline No. & Objek Yang Dievaluasi & Tingkat Kesesuaian & Kriteria Penyesuaian \\
\hline 1 & Kegiatan Pembukuan & $23 \%$ & Sebagian Kecil \\
2 & Kegiatan Inventaris & $46 \%$ & Netral \\
3 & Kegiatan Pelaporan & $33 \%$ & Sebagian Kecil \\
\hline Rata - Rata & $34 \%$ & Sebagian Kecil \\
\hline
\end{tabular}

Sumber: Pengolahan Data, 2019

\section{Evaluasi Kelengkapan KIB SKPD Kabupaten Aceh Singkil}

Dari hasil evaluasi terhadap kelengkapan KIB-A, KIB-B, KIB-C, KIB-D, KIB-E dan KIB-F diperoleh persentase rata-rata tingkat kesesuaian sebesar 81\%, yang berarti kelengkapan pengisian KIB SKPD memenuhi kriteria cukup sesuai dengan Permendagri No. 19 Tahun 2016. Hasilnya terlihat pada tabel berikut ini:

Tabel 4.3 Hasil Evaluasi Kelengkapan Kartu Inventaris Barang (KIB)

\begin{tabular}{llll}
\hline No. & Kartu Inventaris Barang & Tingkat Kesesuaian & Kriteria Penyesuaian \\
\hline $\mathbf{1}$ & KIB - A & $91 \%$ & Sudah Sepenuhnya \\
$\mathbf{2}$ & KIB - B & $85 \%$ & Sudah Sepenuhnya \\
3 & KIB - C & $67 \%$ & Sebagian Besar \\
4 & KIB - D & $64 \%$ & Sebagian Besar \\
5 & KIB - E & $80 \%$ & Sudah Sepenuhnya \\
6 & KIB - F & $99 \%$ & Sudah Sepenuhnya \\
\multicolumn{2}{l}{ Rata - Rata } & $81 \%$ & Sudah Sepenuhnya \\
\hline
\end{tabular}

Sumber: Pengolahan Data, 2017

\section{Kendala Yang Dihadapi Dalam Penatausahaan Aset Tetap Pemerintah Kabupaten Aceh Singkil}

Dengan penatausahaan yang teratur dan tertib, maka akandihasilkan angka-angka yang tepat dan akurat yang berdampak pada tersedianya sumber data yang memadai dalam menyusun perencanaan kebutuhan dan penganggaran serta untuk menghasilkan laporan barang milik daerah dalam penyusunan neraca dengan angka yang tepat dan akurat. Dari hasil evaluasi terhadap prosedur dan dokumen penatausahaan aset tetap, diperoleh persentase tingkat kesesuaian sebesar 57\% yang berarti Pemerintah Kabupaten Aceh Singkil telah melakukan penatausahaan aset tetap cukup sesuai dengan Permendagri No. 19 Tahun 2016. Dari hasil evaluasi, masih ditemukan kendala-kendala yang menyebabkan penatausahaan aset tetap pada Pemerintah Kabupaten Aceh Singkil belum mencapai tingkat kesesuaian 100\%. Kendala-kendala yang dihadapi dalam penatausahaan aset tetap pada Pemerintah Kabupaten Aceh Singkil adalah:

1. Rendahnya etos kerja dan disiplin pengurus barang pengguna

2. Keterbatasan data pendukung aset tetap

3. Minimnya pendidikan dan pelatihan yang berhubungan dengan pengelolaan barang milik daerah 
4. Rendahnya koordinasi dan komitmen pihak-pihak yang terlibat dalam penatausahaan aset tetap

5. Belum adanya penggunaan aplikasi dalam pencatatan barang milik daerah

\section{SIMPULAN}

Dari hasil evaluasi terhadap prosedur penatausahaan aset tetap dan dokumen penatausahaan aset tetap, diperoleh rata-rata tingkat kesesuaian penatausahaan aset tetap pada Pemerintah Kabupaten Aceh Singkil adalah sebesar 57\% yang berarti penatausahaan aset tetap pada Pemerintah Kabupaten Aceh Singkil memenuhi kriteria cukupsesuai dengan Permendagri No. 19 Tahun 2016. Dari hasil evaluasi prosedur penatausahaan aset tetap Pemerintah Kabupaten Aceh Singkil yang terdiri dari kegiatan pembukuan, inventarisasi dan pelaporan diperoleh persentase rata-rata tingkat kesesuaian 34\% yang mana berarti prosedur penatausahaan aset tetap pada Pemerintah Kabupaten Aceh Singkilsebagian kecil sesuai dengan Permendagri No. 19 Tahun 2016. Persentase tingkat kesesuaian prosedur penatausahaan sebesar $34 \%$ merupakan rata-rata tingkat kesesuaian dari kegiatan pembukuan 23\%, kegiatan inventarisasi 46\% dan kegiatan pelaporan 33\%. Dari hasil evaluasi terhadap dokumen penatausahaan aset tetap, yaitu kelengkapan kartu inventaris barang yang terdiri dari KIB-A, KIB-B, KIB-C, KIB-D, KIB-E dan KIB-F, diperoleh persentase tingkat kesesuaian sebesar 81\% yang berarti persentase tingkat kesesuaian kelengkapan kartu inventaris barang memenuhi kriteria sebagian besar sesuai dengan Permendagri No. 19 Tahun 2016. Tingkat kesesuaian kelengkapan KIB sebesar 81\% merupakan nilai rata-rata dari persentase hasil evaluasi KIB-A sebesar 91\%, KIB-B sebesar 85\%, KIB-C sebesar 67\%, KIB-D sebesar 64\%, KIB-E sebesar 80\%, dan KIB-F sebesar 99\%. Kendala-kendala yang dihadapi dalam penatausahaan aset tetap pada Pemerintah Kabupaten Aceh Singkil adalah: rendahnya etos kerja dan disiplin pengurus barang pengguna, keterbatasan data pendukung aset tetap, minimnya pendidikan dan pelatihan yang berhubungan dengan pengelolaan barang milik daerah, rendahnya koordinasi dan komitmen pihak-pihak yang terlibat dalam penatausahaan aset tetap, dan belum adanya penggunaan aplikasi dalam pencatatan barang milik daerah.

\section{DAFTAR PUSTAKA}

Arikunto, (2006). Metodologi Penelitian. Bina Aksara.Yogyakarta.

Bungin, B, (2007). Penelitian Kualitatif: Komunikasi, Ekonomi, Kebijakan Publik dan Ilmu Sosial lainnya. Jakarta: Putra Grafika.

Cholid, (2008), Metodologi Penelitian, Jakarta: PT Bumi Aksara.

Juliansyah, (2010), Metodelodi Penelitian, Kencana.

Hermaningsih. (2009). Pengaruh Partisipasi dalam Penganggaran dan Peran Manajerial Pengelola Keuangan Daerah terhadap Kinerja Pemerintah Daerah. Program Pasca Sarjana. Universitas Diponegoro.

Komite Standar Akuntansi Pemerintahan, (2014). Buletin Teknis Nomor 15 Tentang Akuntansi Aset Tetap Berbasis Akrual.

Komite Standar Akuntansi Pemerintahan, (2014). Buletin Teknis Nomor 18 tentang Akuntansi Penyusutan Berbasis Akrual. 
Mahmudi. (2010). Efektivitas Organisasi. Edisi ke dua. Penerbit STIM YKPN, Yogyakarta.

Sholeh, C. dan Rachmansjah, H. (2010). Pengelolaan Keuangan dan Aset Daerah. Fokus Media: Jakarta.

Sugiama, A.G. (2013). Manajemen Aset Pariwisata, Guardaya Intimarta: Bandung.

Sumini, (2010). Penatausahaan Barang Milik Daerah, STAN.

Siregar, (2014), Manajemen Aset. Jakarta, Gramedia Pustaka Utama.

Yusuf, M. (2010), "Delapan Langkah Pengelolaan Aset Daerah Menuju Pengelolaan Keuangan Daerah Terbaik", Salemba Empat, Jakarta.

Siregar, A.B., Kusmanto, H. \& Isnaini. (2016), Evaluasi Kinerja Kepala Sekolah Menengah Kejuruan SeKabupaten Langkat Tahun 2015, Jurnal Administrasi Publik, 6 (1): 13-19

Suyono, \& Kadir, A. (2014), Fungsi Pengelolaan Arsip Dalam Rangka Meningkatkan Efektivitas Kerja Pada Balai Pengelolaan Hutan Mangrove Wilayah II, Jurnal Administrasi Publik Universitas Medan Area, 2 (2): 101-106.

Sari, D., \& Ritonga, S. (2016). Peran Dinas Kebersihan Dalam Pengelolaan Sampah Rumah Tangga di TPA Terjun Kecamatan Medan Marelan, Jurnal Administrasi Publik Universitas Medan Area, 4 (1): 6573

Laniari, M., \& Muda, I. (2016). Pelaksanaan Pengelolaan Kebijakan Alokasi Dana Nagori (ADN) Dalam Meningkatkan Pembangunan Nagori di Kecamatan Bandar Huluan Kabupaten Simalungun, Jurnal Administrasi Publik Universitas Medan Area, 4 (2): 131-142

UNDANG - UNDANG

Peraturan Menteri Dalam Negeri Nomor 19 Tahun 2016 tentang Pedoman Pengelolaan Barang Milik Daerah.

Peraturan Menteri Dalam Negeri Nomor 108 Tahun 2016 tentang Penggolongan dan Kodefikasi Barang Milik Daerah.

Peraturan Pemerintah Republik Indonesia Nomor 27 tahun 2014 tentang Pengelolaan Barang Milik Negara/Daerah.

Peraturan Pemerintah Republik Indonesia Nomor 24 Tahun 2005 tentang Standar Akuntansi Pemerintahan.

Qanun Aceh Singkil Nomor 4 Tahun 2016 tentang Pembentukan dan Susunan Perangkat Daerah Kabupaten Aceh Singkil.

Qanun Aceh Singkil Nomor 2 Tahun 2019 tentang Pengelolaan Barang Milik Daerah.

Peraturan Bupati Aceh Singkil Nomor 24 Tahun 2016 tentang Kedudukan, Susunan Organisasi, Tugas dan Tata Kerja Badan Pengelolaan Keuangan Kabupaten. 